\title{
CAMA
}

Centre for Applied Macroeconomic Analysis

\section{Can Older Workers Stay Productive? The Role of ICT Skills and Training}

\section{CAMA Working Paper 4/2021 January 2021}

Jong-Wha Lee

Korea University

Centre for Applied Macroeconomic Analysis, ANU

\section{Do Won Kwak}

Korea University

\section{Eunbi Song}

Korea University

\section{Abstract}

This paper quantitatively examines the effects of aging on labor productivity using individual worker data in Korea. We find that attainment of information and communications technology (ICT) skills and participation in job-related training can help older workers stay productive. The estimation results present that ICT skills attainment has a positive effect on the wages of the older workers aged 50-64 with a high level of education or in a skill-intensive occupation. Job training also has a significant positive effect on the wages of older workers. Even compared to younger workers, older welleducated workers can be more productive through higher ICT skills attainment and jobtraining participation. The evidence suggests that a productivity decrease in line with the aging process can be mitigated by training aging workers to equip themselves with ICT skills. 


\section{Keywords}

aging, education, information and communications technology, productivity, skill, training

\section{JEL Classification}

$\mathrm{J} 14, \mathrm{~J} 24, \mathrm{~J} 31, \mathrm{O} 47$

\section{Address for correspondence:}

(E) cama.admin@anu.edu.au

\section{ISSN 2206-0332}

The Centre for Applied Macroeconomic Analysis in the Crawford School of Public Policy has been established to build strong links between professional macroeconomists. It provides a forum for quality macroeconomic research and discussion of policy issues between academia, government and the private sector.

The Crawford School of Public Policy is the Australian National University's public policy school, serving and influencing Australia, Asia and the Pacific through advanced policy research, graduate and executive education, and policy impact. 


\title{
Can Older Workers Stay Productive? The Role of ICT Skills and Training*
}

\author{
Jong-Wha Lee ${ }^{+}$ \\ Korea University and Centre for Applied Macroeconomic Analysis, ANU \\ Do Won Kwak ${ }^{++}$and Eunbi Song ${ }^{+++}$ \\ Korea University
}

January 2021

\footnotetext{
* The authors thank Bruce Chapman, Jongsuk Han, Tomoo Kikuchi, Jinill Kim, Warwick McKibbin, Kwanho Shin, and the conference participants at Australian National University and Korea University for their helpful comments. This research was supported by the ARC Centre of Excellence in Population Ageing (ARC Grant number CE170100005) and a Korea University Grant.

+ Corresponding author: Economics Department, Korea University and Centre for Applied Macroeconomic Analysis (CAMA), Australian National University. E-mail: jongwha@korea.ac.kr.

${ }^{++}$Graduates School of International Studies, Korea University, 145 Anam-ro, Seongbuk-gu, Seoul, 02841, Republic of Korea. E-mail: dwkwak@korea.ac.kr

${ }^{++}$Economics Department, Korea University, 145 Anam-ro, Seongbuk-gu, Seoul, 02841, Republic of Korea. Email: eunbisong56@,korea.ac.kr
} 


\begin{abstract}
This paper quantitatively examines the effects of aging on labor productivity using individual worker data in Korea. We find that attainment of information and communications technology (ICT) skills and participation in job-related training can help older workers stay productive. The estimation results present that ICT skills attainment has a positive effect on the wages of the older workers aged 50-64 with a high level of education or in a skill-intensive occupation. Job training also has a significant positive effect on the wages of older workers. Even compared to younger workers, older well-educated workers can be more productive through higher ICT skills attainment and job-training participation. The evidence suggests that a productivity decrease in line with the aging process can be mitigated by training aging workers to equip themselves with ICT skills.
\end{abstract}

Keywords: aging, education, information and communications technology, productivity, skill, training

JEL Classification Codes: J14, J24, J31, O47 


\section{Introduction}

An aging population is an urgent challenge in South Korea (Korea, henceforth). Korea's economy has been experiencing a drastic demographic shift toward an aged society where elderly citizens aged over 65 years will make up a third of its population in 2040 - more than double from the $15 \%$ that was tabulated in 2019 (Figure 1). The pace of aging within the workforce is faster than any other economy. The share of workers aged 50-64 years over the working-age population aged 15-64 years began rapidly rising since 1990. It has more than doubled from the $16 \%$ figure in 1990 to the $33 \%$ that was noted in 2019 . By 2050, it is expected to continue to rise, outpacing Japan and Germany (Figure 2). With a common belief that older workers tend to be less productive than their younger counterparts, an aging workforce remains as one of the most urgent challenges that the Korean economy will face in the coming years.

2019

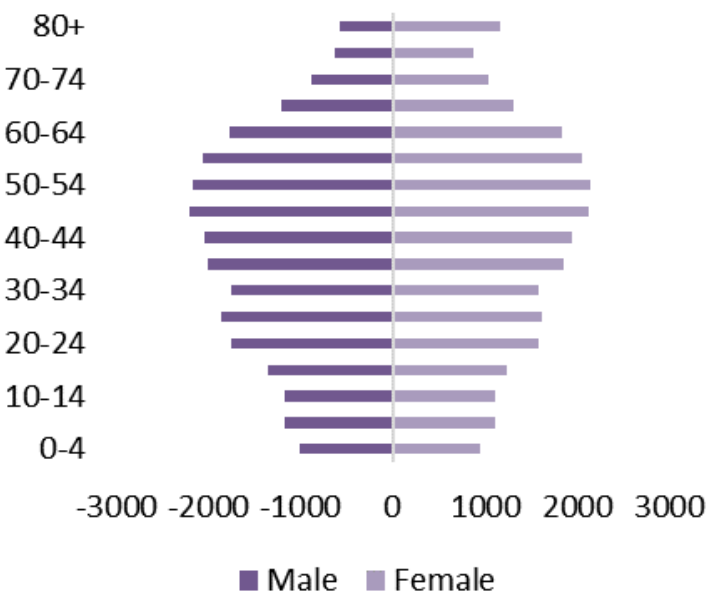

2040

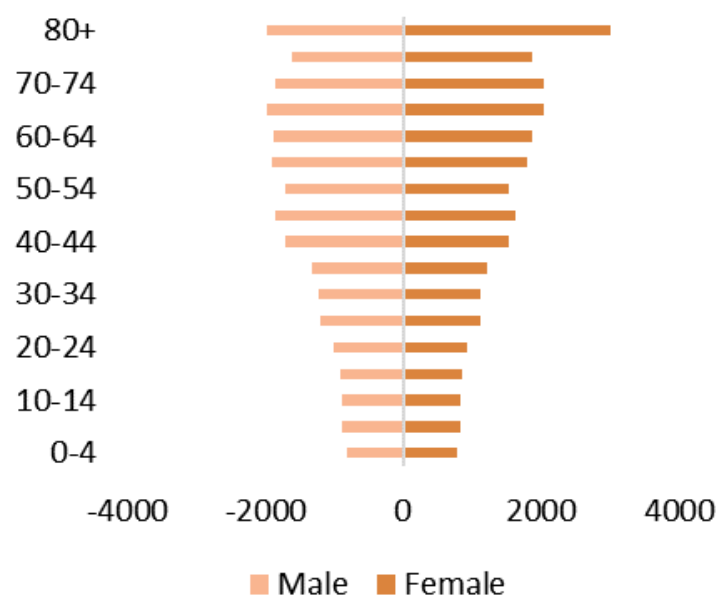

Source: Authors' construction from UN (2019), World Population Prospects, The 2019 Revision, UN, New York.

Figure 1 Population Age Structure in Korea, Selected Years (thousands) 


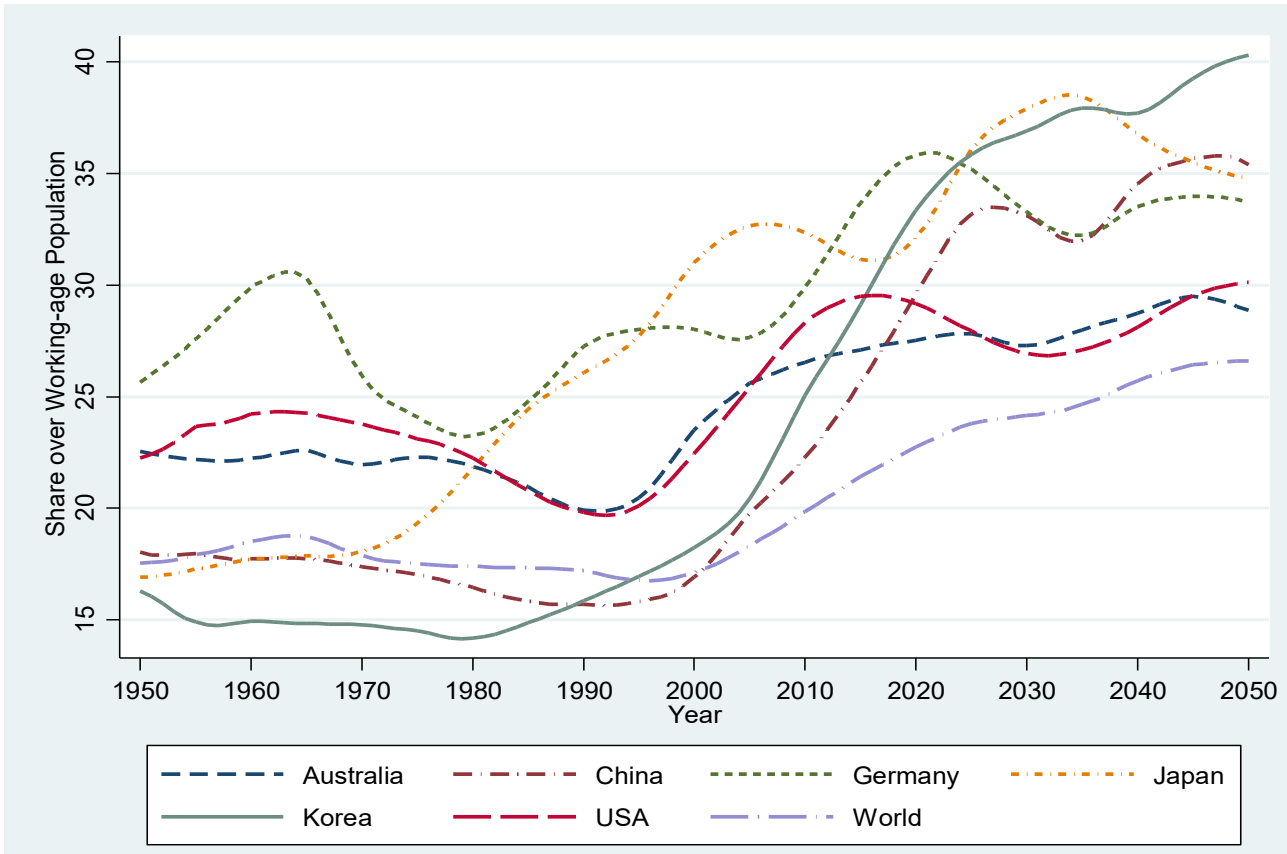

Source: Authors' construction from UN (2019)'s World Population Prospects.

Figure 2 Share of Workers Aged 50-64 over Working-age Population (16-64 years)

An increase in older workers may hinder economic growth if the older workers are less productive than the younger workers. This is from the deterioration of the physical and cognitive abilities, which comes along with age and the low tendency to adapt to new technologies. Maintaining the productivity of older workers is not an easy task. However, if older workers are more educated and continue to improve their human capital through their work experience, job training, and acquisition of new skills after their formal education, they can stay productive.

In Korea, along with the rapid growth of the information and communications technology (ICT) sector and the heavy investment in new technologies in the economy (Lee et al., 2020), 
acquisition of ICT skills has also been active-for instance, through formal education. ${ }^{1}$ Korea's ICT use in education essentially began with improving students' computer literacy, followed by continued reinforcement of human and physical infrastructure; based on this approach, there were increased learning opportunities using ICT. For instance, ICT education was activated during the 2001-2005 period. The national curriculum allowed primary and secondary schools to launch an independent course for teaching basic computer and word processing skills for their students. This helped students familiarize with computers and utilize them in their daily lives. For instance, primary students learned how to turn the computers on and off, and how to find information using the internet browser, whereas secondary students were taught how to communicate via the internet and produce documents using word processors.

However, despite a relatively large investment in ICT, there is a question of whether all Korean workers possess adequate cognitive skills required to effectively perform their tasks in the era of information and automation intelligence (AI) technologies. According to the Programme for the International Assessment of Adult Competencies (PIAAC) published by the Organisation for Economic Co-Operation and Development (OECD), Korean adults who participated in the PIAAC survey scored below the OECD average in "problem-solving skills in technology-rich environments," which involved ICT skills (KRIVET, 2013). Whereas their score for literacy proficiency was above the OECD average. There is also a large differential in ICT skills proficiency between older and younger age groups. Another notable feature is that the participation rate in on-the-job training for the aged group in Korea is lower than other OECD countries,

\footnotetext{
1 The Korean government sequentially developed ICT education. There are three phases of ICT education development according to the Ministry of Education and KERIS (2014): Phase I, Foundation Establishment, over the period of 1996 to 2000; Phase II, Dissemination and Settlement, from 2001 to 2005; Phase III, Advancement, from 2006 to 2010; Phase IV, Education Converged with Technologies, from 2010 to 2014.
} 
including the United States (US), Japan, and Nordic countries (World Bank, 2016). Figure 3 shows that the job-training participation rate for older workers is much lower than the average of the OECD countries, while the rate for prime-age workers (30-49) is only slightly lower than the OECD average.

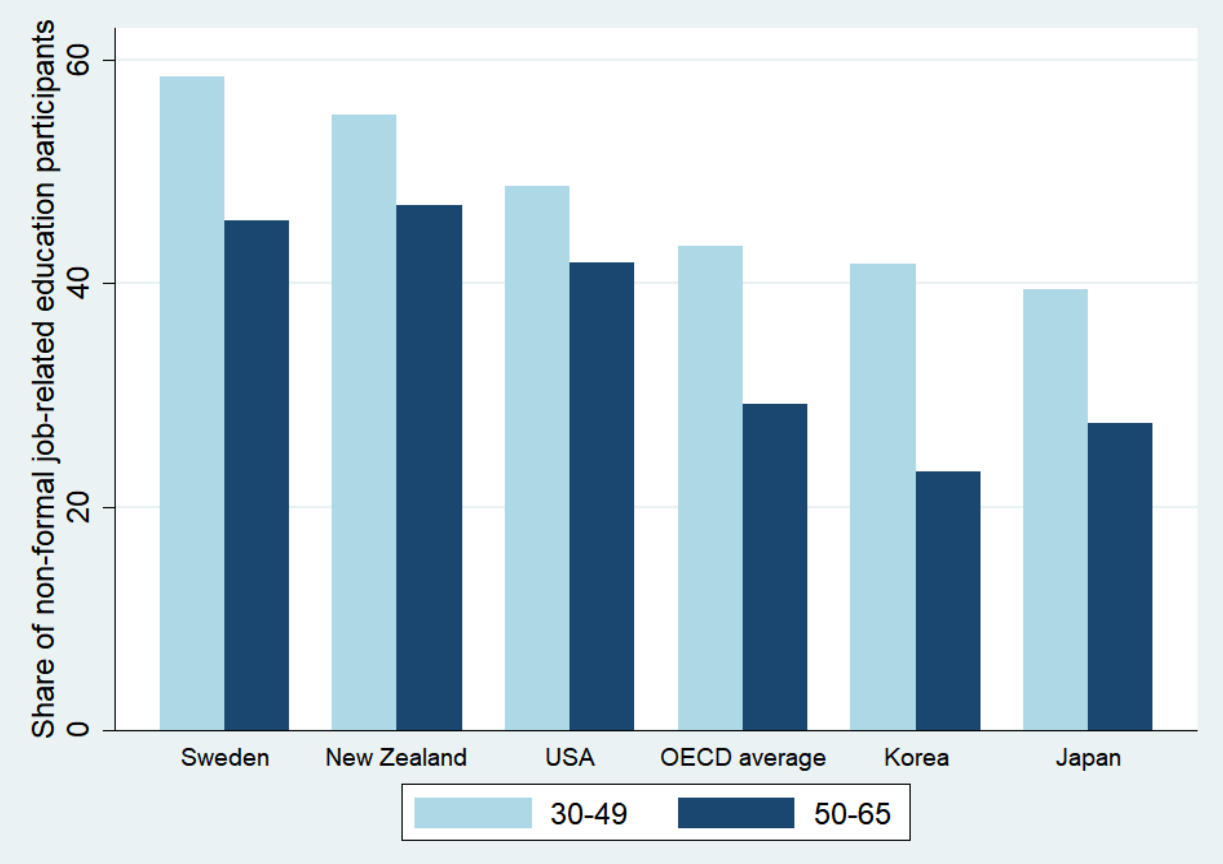

Note: The figures measure a share of those who participated in non-formal job-related education (that is job training) in the previous 12 months at the time of the PIAAC survey among all the respondents.

Source: Authors' construction from the OECD (2013a)'s PIAAC Data.

Figure 3 Participation rates for job training in selected economies

This study builds on three lines of previous literature, including: 1) those examining the aging effects on productivity; 2) those exploring the role of ICT skills attainment on worker's productivity; and 3) those assessing the role of job training participation in improving worker's productivity. Aging tends to have detrimental effects on productivity as the human capital of an individual declines with age, owing to the deterioration of their physical and cognitive capacities 
(Truxillo, et al., 2015). Some empirical studies—including Heckman et al. (2003)—show a humpshaped age-profile of wages. In addition, adapting to new technology tends to leave them behind. The knowledge and skills the older workers had acquired during their formal education are often outdated (ADB, 2018), and they tend to have lower adoption rates of new technologies than younger workers (Meyer, 2011).

On the other hand, there are other studies showing that aging does not necessarily accompany productivity declines. If older workers are more educated or continuously develop their human capital after their formal education by adapting to new technologies, having longer work experience, participating in on-the-job training, and equipping themselves with proper skills, their productivity might not necessarily be lower than that of younger workers. Along with a longer lifespan, workers have a greater willingness to work longer, thus having a higher motivation to invest in their health and education (Vogel et al., 2017; Prettner et al., 2013). Borsch-Supan and Weiss (2016), using data from a truck assembly plant in Germany, provide evidence that the increase in productivity of individuals up to the age of 60 can be explained by longer work experience and non-cognitive abilities, such as communication skills. Furthermore, firm-level studies across the countries suggest that productivity peak tends to be around the ages $30-45$, but the range varies across countries and industries, as summarized in Chomik and Piggott (2019). The Asian Development Bank (2018) reports that there are some sectors where workers may exhibit a higher productivity rate, even at the later stages of their careers. Burtless (2018) further argues that there is little evidence for the negative link between aging and productivity in the US. To sum it up, previous studies on the effect of aging on productivity remain inconclusive.

ICT skills attainment becomes important for individuals to stay productive at the time of rapid advances in ICT and automation technologies (World Bank, 2016). It also indicates that the 
race between skills and technology could bring about the digital divide between those who can use and complement digital technologies and those who have limited access and skills. Falck, Heimisch-Roecker, and Wiederhold (2020) report positive returns to ICT skills, reflecting a significant role that ICT skills play in determining the labor productivity of individuals. They find that workers with a higher ICT skills proficiency earn $27 \%$ more than those with a low proficiency on average in the PIAAC data. They also report that workers with no computer experience earn around $10 \%$ less than those with the most basic computer skills. Hanushek et al. (2015) investigate returns on skills across 23 economies using the PIAAC data and report that ICT skills are positively associated with individual earnings. The returns on ICT skills are estimated around 15.3\% in Korea. Lee and Wie (2016) also show significantly positive returns concerning ICT skills in Japan and Korea.

There exists a considerable amount of empirical studies on the effects of job training on wages and the productivity of trainees. According to literature reviews by Leuven (2004), Almedia and Faria (2014), and Cegolon (2015), many studies report positive effects of job training on worker's earnings and productivity. The average wage effects are estimated around 5-10\% in the United Kingdom (UK) and the US (Leuven, 2004); around 3.7-21.6\% for European countries (Bassanini et al., 2005); and around 2.6-9.0\% for Korea (Yoo \& Kang, 2010). Contrarily, other studies could not find any significant positive effects (Pischke, 2001; Goux \& Maurin, 2000). Some studies have also assessed such effects across age groups. Picchio and van Ours (2013) and Berg et al. (2017) document that vocational training, especially on-the-job training, is effective in improving productivity for both younger and older workers, although the effect decreases with age. They are also consistent with the meta-analysis done by Haelermans and Borghans (2012). This differential in training can be attributable to the different motives of younger and older 
workers, as suggested by Lang (2012) and Dostie and Léger (2014). However, the studies aimed at examining job training for older employees do not always show positive wage effects (Göbel \& Zwick, 2013). A recent study by Lee, Han and Song (2019) using the Korean sample from the PIAAC provides evidence that the wage effects of job-related training are positive and have larger effects for the older workers. Overall, the effects of job training depend on the data, econometric methods, and their contexts.

This paper builds on those three lines of literature on the aforementioned topics and contributes to them by investigating the effects of ICT skills attainment and job training on the productivity of older workers in Korea. ${ }^{2}$ Additionally, using various econometric techniques, we attempt to address the possible sources of endogeneity bias in estimating the empirical specification that is an extended version of the Mincer wage equation. One of the key issues is a missing data problem. Given the characteristics of the PIACC survey, individuals who had no experience in computer and/or failed the ICT core/basic assessment do not have scores for ICT skills proficiency and those with missing data are not random. It is highly likely that they have characteristics that are negatively correlated with wages. To control for missing data problems, we adopt a regression imputation method where we use literacy and numeracy scores to predict missing ICT skills scores, and also adopt an inverse probability weight (IPW) method to adjust for unequal sampling distribution. The estimation results are robust using the two different econometric tools. The other major empirical issue is how to control for selection biases. There are two types of selection biases in our analysis: an individual's decision to participate in the labor market (sample selection bias); and an individual's decision to attain ICT skills and/or to receive

\footnotetext{
2 This paper is a companion paper for Lee, Song and Kwak (2020) which examine aging effects on productivity and a role of ICT capital investment in counterbalancing such aging effects using industry-level data. As a complement, this paper assesses such topics using individual-level data.
} 
a job-training course, caused by his/her wage expectation (self-selection bias). Because of the difficulties in finding the appropriate instruments for ICT skills attainment and/or job-training participation, we attempt to adopt various econometric tools, and the estimation results turn out to be robust when using the IPW to control for the selection biases.

The remainder of this paper is organized into five sections. Section 2 provides our empirical specification; Section 3 describes the data; Section 4 examines the wage effects of ICT skills and job training at an individual-level, especially for older workers; Section 5 discusses identification strategy; and Section 6 presents the conclusion.

\section{Empirical Specification and Strategy}

Over their lifetime, an individual spends a certain period of time in formal schooling and for work after their completion of their formal education. An individual $j$ obtains an educational level of $S_{j}$ and continues to accumulate his/her own human capital via work experience and job training. We consider that an individual can develop cognitive and non-cognitive capabilities as well as technical skills that can command and complement ICT technologies. Then, the human capital attained determines the worker's productivity or wages in the labor markets. We can write the worker's productivity or wages, using the Mincerian wage equation, as follows (Mincer, 1974; Acemoglu, 2009): ${ }^{3}$

$$
\begin{gathered}
\log \mathrm{W}_{\mathrm{j}}=\alpha+\beta_{\mathrm{G}} \text { Gender }_{j}+\gamma_{s} \text { School }_{j}+\gamma_{e} \exp _{j}+\gamma_{e_{2}} \exp _{j}^{2}+\gamma_{\mathrm{ICT}} \text { ICT Skills }_{j}+ \\
\gamma_{\mathrm{T}} \text { Training }_{j}+\varepsilon_{j}
\end{gathered}
$$

\footnotetext{
3 We include a gender dummy in the wage equation to control for the wage differential by gender. When our specifications of (1), (2) and (3) without a gender dummy are applied to the sample of male workers, the main results remain robust.
} 
where $\log \mathrm{W}_{\mathrm{j}}$ is the logarithm of individual $j$ 's wage that captures the worker's productivity. Wages are determined by the individual's educational level $\left(S c h o o l_{j}\right)$, work experience $\left(\exp _{j}\right)$, ICT skills (ICT Skills $s_{j}$ ), and job training $\left(\operatorname{Training}_{j}\right)$. Gender $_{j}$ is a female indicator representing whether a worker is female.

Specifically, experience in Equation (1) is often measured by years of potential labor market experience, which is typically defined as age or age minus year of schooling minus six. Potential labor market experience may be a good approximation. However, there is a discrepancy between potential and actual labor market experience. As this paper aims to estimate the "pure" age effect, we will include both age and actual labor market experience variables in the model as presented in Equation (2) and Equation (3). The age effect that we are interested in denotes the wage effect of age after controlling (actual) labor market experience and other explanatory variables, including gender, education attainment, ICT skills, and participation in job training. In addition, we will consider the age structure of workers as another key factor for determining the effects of ICT skills and training on labor productivity. We will explore whether ICT skills attainment and training can have relative beneficial effects on the wages of the old workers aged 50-65 years, compared to the young workers.

We set up an extended version of the Mincer wage equation to examine the pure effects of aging as well as the effects of ICT skills and job training on labor productivity across age groups. We examine the interaction effects among ICT skills attainment, job training, and the age of the workers. To elaborate, we are interested in whether ICT skills attainment and training can have relative beneficial effects on the wages of the older workers in age range 50-65 years, compared to the younger workers. We extend the Mincer wage equation—Equation (1) — by introducing ICT 
skills proficiency scores, an indicator of job-training participation and their interaction terms with age-group dummies:

$$
\begin{aligned}
& \log \mathrm{W}_{\mathrm{j}}=\alpha+\beta_{\mathrm{G}} \text { Gender }_{j}+\beta_{\mathrm{s}} \text { School }_{j}+\gamma_{\mathrm{e}} J_{\text {Job_exp }}+\gamma_{\mathrm{a}} A_{j}+\gamma_{\mathrm{a}_{2}} A_{j}^{2}+\gamma_{I C T} I C T_{-} S K I L L_{j} \\
& +\gamma_{I C T, A G E}\left(I C T \_S K I L L_{j} * A G E_{-} G R O U P_{j}\right)+\gamma_{\mathrm{T}} \text { Training }_{j}+\gamma_{T, A G E}\left(\text { Training }_{j} *\right. \\
& \left.A G E_{-} G R O U P_{j}\right)+\mu_{i}+\mathrm{O}_{k}+\gamma_{\mathrm{L}} \text { Literacy }_{j}+\varepsilon_{j},
\end{aligned}
$$

where $\log W_{j}$ is the logarithm of hourly earnings of individual $j, S_{c h o o l}$ is a dummy for four educational attainment levels, which are lower secondary and below (HSD), upper secondary (HSG), college education (SME), and university and above (CLC). As mentioned earlier, instead of years of potential experience, we include $J O B_{-} E X P_{j}$ in the empirical model, which is Equation (2). It denotes the actual years of labor market experience that the individual $j$ has, that is measured in years of paid work during his/her lifetime in the PIAAC survey. The model also has $A_{j}$ as the age of individual $\mathrm{j}$ and its squared term to measure the pure aging effect, thereby the parameters $\gamma_{a}$ and $\gamma_{a_{2}}$ capture the effects of aging on wages of individuals.

Then, we add a measure of ICT skills proficiency scores $\left(I C T_{-} S K I L L_{j}\right)$ of an individual worker and an indicator of job training participation $\left(\right.$ Training $\left._{j}\right)$, respectively. The indicator for job-training participation presents whether an individual $j$ had taken non-formal job-related education at least once in the previous 12 months at the time of the PIAAC survey. It takes a value of either one or zero representing participation or non-participation. Then, the effects of ICT skills attainment and job-training participation on wages are captured in the parameters $\gamma_{I C T}$ and $\gamma_{T}$, respectively.

This model includes an interaction term between a measure of ICT skills $\left(I C T_{-} S K I L L_{j}\right)$ and age-group dummies $\left(A G E_{-} G R O U P_{j}\right)$ to explain how the wage effects of ICT skills differ by 
age groups. An interaction term ( Training $\left._{j} * A G E_{-} G R O U P_{j}\right)$ is added to identify differential training effects among the age groups. The Korean full-time workers in our sample are classified into three age groups: 16-29 years, 30-49 years, and 50-65 years. In this empirical model, we are interested in the parameters $\gamma_{I C T}$ and $\gamma_{I C T, A G E}$, which capture the relative wages of ICT skills on earnings across age groups, and the parameters $\gamma_{T}$ and $\gamma_{T, A G E}$, which measure the relative training effects on earnings across age groups.

Occupation and industry fixed effects $\left(\mathrm{O}_{k}\right.$ and $\mu_{i}$, respectively) are also included to control for potential bias arising from the correlation between unobserved confounding factors and industry or occupational characteristics. Thus, for instance, in the estimation of the effect of ICT skills on wages, we compare workers within the same industry and the same occupation groups. Furthermore, even within the same industry and occupation groups, workers unobserved ability, such as innate ability, could be still correlated with ICT skills so that able workers are more likely to have high ICT skills. Thus, to control for endogeneity bias sourced from unobserved ability, we add measures of literacy skills proficiency $\left(\right.$ Literacy $\left._{j}\right)$ in the model.

Furthermore, we attempt to identify who will receive benefits from a higher level of ICT skills attainment among the old by adding two different interaction terms to Equation (2). One is between ICT skills, age-group dummies, and an indicator for receiving a tertiary level of education and the other is between ICT skills, age-group dummies, and an indicator for employment in a skill-intensive occupation. Then, we can construct Equation (3):

$$
\begin{gathered}
\operatorname{Ln}\left(\mathrm{W}_{j}\right)=\alpha+\beta_{\mathrm{X}} G_{e n d e r_{j}}+\beta_{\mathrm{x}} \text { School }_{j}+\gamma_{\mathrm{e}} J o b_{e x p}+\gamma_{\mathrm{a}} A_{j}+\gamma_{\mathrm{a}_{2}} A_{j}^{2}+ \\
\gamma_{I C T} I C T_{-} S K I L L_{j}+\gamma_{I C T, A G E}\left(I C T_{-} S K I L L_{j} * A G E_{-} G R O U P_{j}\right)+ \\
\gamma_{I C T, A G E, H i g h_{E D U}}\left(I C T \_S K I L L_{j} * A G E_{-} G R O U P_{j} * H i g h_{-} E d u_{j}\right)+
\end{gathered}
$$




$$
\begin{aligned}
& \gamma_{I C T, A G E, S k i l l o c C}\left(I C I_{-} S K I L L_{j} * A G E_{-} G_{\text {GROUP }} * \text { Skill_OCC }_{j}\right)+\gamma_{\mathrm{T}} \text { Training }_{j}+ \\
& \gamma_{T, A G E}\left(\text { Training }_{j} * A G E_{-} G R O U P_{j}\right)+\mu_{i}+\mathrm{O}_{k}+\gamma_{\mathrm{L}} \text { Literacy }_{j}+\varepsilon_{j}
\end{aligned}
$$

where $H_{i g h} E d u_{j}$ is an indicator for receiving a high level of education, which refers to tertiary education (college and university and above), and Skill_OCC $C_{j}$ is an indicator for whether an individual $j$ is employed in a skill-intensive occupation. Using this empirical model, we attempt to examine whether older workers who received a high level of education or are employed in a skillintensive occupation may gain a relative benefit from the acquisition of ICT skills compared to their counterparts.

However, in estimating the abovementioned empirical models, there is a missing data problem such that the ICT skills proficiency measure is available only for individuals who took the computer-based assessment. For those who had never used a computer, those who refused to take the computer-based assessment and instead took the paper-and-pencil version, and those who failed the ICT core/basic assessment, the proficiency scores for ICT skills are not available. In total, in our sample, the proportion of these individuals without ICT skills proficiency scores is 25.6\%. Unfortunately, those individuals with missing data are not random. They are most likely to have characteristics that are negatively correlated with their wage. For instance, those who had never used a computer are more likely to have a low level of educational attainment which is associated with a low wage. The effect of ICT skills would be overestimated if missing data is ignored.

Thus, we account for the missing data problem with an imputation method. In the estimation of imputation models, we use a regression imputation where literacy and numeracy test scores are adopted as main variables to predict the missing ICT skills measure. Literacy and numeracy test scores are good predictors in the regression model because we have test scores of 
literacy and numeracy for all individuals in the sample. Accordingly, the correlation between literacy and ICT skills and the correlation between numeracy and ICT skills are 0.81 and 0.77 , respectively. We try various model specifications that differ in predictors by the degree of included individual characteristics $\left(X_{j}\right)$ in the regression models.

$$
\text { ICT_SKILL } L_{j}=\alpha+\beta_{1} \cdot \text { literacy }_{j}+\beta_{2} \cdot \text { numeracy }_{j}+X_{j} \pi+u_{j}
$$

To avoid overfitting the problem of one-time imputation of the missing ICT_SKILL $L_{j}$, we introduce residual variance to predicted missing variables by using multiple imputation (MI) methods (Rubin, 1987; Little \& Rubin, 2002). For instance, in the estimation of $\gamma_{I C T, A G E}$ in Equation (9), for each imputation we estimate $\hat{\gamma}_{I C T, A G E, j}$ and we repeat this process $\mathrm{M}$ times $(j=$ $1,2, \ldots, M)$, and the MI estimate for $\gamma_{I C T, A G E}$ is $\hat{\gamma}_{I C T, A G E, M I}=\frac{1}{M} \sum_{j=1}^{M} \hat{\gamma}_{I C T, A G E, j}{ }^{4}$ In sum, we account for the sample selection issue due to missing data by applying multiple imputation methods while using occupation and industry fixed effects as well as the literacy variable to account for the omitted variable (e.g., unobserved individual ability) bias.

\section{Data}

To analyze the effects of aging on labor productivity, we use the Korean sample from the PIAAC survey. The PIAAC survey is an internationally comparable dataset developed by the OECD (2013). It is based on the surveys of approximately 166,000 adults, aged $16-65$ years, from

\footnotetext{
${ }^{4}$ See Little and Rubin (2002) for more details and the formula to get the standard error for the estimate.
} 
24 countries. $^{5}$ The Korean sample consists of 6,667 respondents, and provides their detailed information including age, gender, education attainment, and job characteristics.

We restrict our sample to have only the full-time workers who worked more than 30 hours per week. We exclude the self-employed from our sample, because their wages are not reported in the dataset. Then, our analysis is applied to 2,710 Korean full-time workers.

A notable feature of the PIAAC survey is to provide measures of adult skills proficiency in three domains-literacy, numeracy, and problem solving in technology-rich environments. The PIAAC defines problem solving in technology-rich environments as "using digital technology, communication tools and networks to acquire and evaluate information, communicate with others and perform practical tasks" (OECD, 2013a). It focuses on problems that are closely related to the use of ICT and requires respondents to take the computer-based assessment. Hence, we consider it as a measure of ICT skills proficiency. As reported in OECD (2013b), unlike literacy and numeracy proficiency assessments, proficiency scores for ICT skills are only available for the respondents who had some experience with computers and were able to take the computer-based assessment. ICT skills are not available for those who had never used a computer (15.5\%); those who rejected to take the computer-based assessment and took the paper-and-pencil version (5.4\%); and those who failed the ICT basic/core assessment (9.1\%) (KRIVET, 2013).

Table 1 describes the characteristics of the Korean respondents in our sample. The Korean respondents were about 40.0 years old, on average. About $42.3 \%$ of them were female. The average hourly wage was estimated to be around 12,812 Korean won. The mean scores in the literacy test

\footnotetext{
5 This is a cross-section dataset. Currently, the OECD is preparing for the second wave of the PIAAC survey. Once the second wave of the PIAAC survey is completed and published, we believe we can make more efforts to address endogeneity issues in measuring the effects of aging on labor productivity and the effects of ICT skills proficiency and job training on the labor productivity of older workers.
} 
and the ICT test were 285.5 and 275.8 out of 500 , respectively. We classify educational attainment of the respondents in the following four levels: lower secondary and below (HSD), upper secondary (HSG), college education (SME), and university and above (CLC). The respondents who completed HSG formed the largest group, amounting to $37.7 \%$, followed by the graduates with CLC (29.0\%) and those with college degrees (21.1\%). The lowest share was of those with HSD (12.2\%). About 51.9\% of the respondents reported that they had participated in non-formal job-related education, that is job training, in the previous 12 months at the time of PIAAC survey. We construct additional education attainment variables by classifying them into two levels-loweducated (HSD and HSG) and highly educated (SME and CLC).

In addition, using the information on occupation measures based on skill level (ISCO-08), we classify the workers' occupation into two levels: skill-intensive and non-skill-intensive. A skillintensive occupation refers to a skilled or semi-skilled white-collar occupation that requires an individual to conduct complex, technical, and practical tasks including decision-making with extensive professional knowledge. In contrast, a semi-skilled blue-collar or elementary occupation is considered as not a skill-intensive occupation, and the individual is required to perform simple, routine physical or manual tasks including operating machinery. In our sample, $67.5 \%$ of the fulltime workers were employed in a skill-intensive occupation. 
Full-time Korean workers

\begin{tabular}{|c|c|c|}
\hline Variables & Mean & Standard deviation \\
\hline \multicolumn{3}{|l|}{ Skills Proficiency Score } \\
\hline $\begin{array}{l}\text { Problem solving in a technology-rich environment } \\
\text { (ICT skills score) }\end{array}$ & 286 & 33.5 \\
\hline Normalized ICT skills score & 0.075 & 0.968 \\
\hline - Not having an ICT skills score & 0.256 & \\
\hline Literacy skills score & 276 & $38.1(0.982)$ \\
\hline Normalized literacy skills score & 0.083 & \\
\hline \multicolumn{3}{|l|}{ Basic Background } \\
\hline Age (years) & 40.0 & 11.1 \\
\hline 16-29 group (share) & 0.218 & \\
\hline 30-49 group (share) & 0.556 & \\
\hline 50-65 group (share) & 0.226 & \\
\hline Female (share) & 0.423 & \\
\hline Hourly wage (Korean won) & 12,830 & 8,893 \\
\hline \multicolumn{3}{|l|}{ Educational Background (share) } \\
\hline \multicolumn{3}{|l|}{ Low level of education } \\
\hline Lower secondary and below (HSD) & 0.122 & \\
\hline Upper secondary (HSG) & 0.377 & \\
\hline \multicolumn{3}{|l|}{ High level of education } \\
\hline Tertiary - College (SMC) & 0.211 & \\
\hline Tertiary - University and above (CLC) & 0.290 & \\
\hline Participation in non-formal job-related education & 0.519 & \\
\hline \multicolumn{3}{|l|}{ Occupation/Jobs (share) } \\
\hline Skill-intensive & 0.675 & \\
\hline No. of Observations & & 710 \\
\hline
\end{tabular}

Note: The sample consists of full-time Korean workers aged 16-65 who worked at least 30 hours per week. Source: PIAAC data from the OECD (2013a).

Table 1 Descriptive Statistics of the Korean PIAAC data 
Figure 4 illustrates two wage-age profiles using our individual-worker level data. The estimated wage-age profile, without controlling for other control variables-labeled as unadjusted wage-age profile in Figure 5-is consistent with the previous studies supporting a hump-shaped relationship between wage and age. The unadjusted wage-age profile in Figure 5 shows that wages increase until the worker reaches the age of around 42 and then it begins to rapidly decline. The decline at the later age may be attributable to the worker's education, job characteristics, and/or innate ability. On the other hand, after controlling the factors including the worker's gender, education, job characteristics and literacy skills, productivity or wage does not show a steep decline at the later age, as can be seen in the adjusted wage-age profile in Figure 5. Note that literacy skills is used as a proxy for the innate ability. In addition, acquisition of ICT skills and participation in job training may further work against the decrease in a worker's productivity.

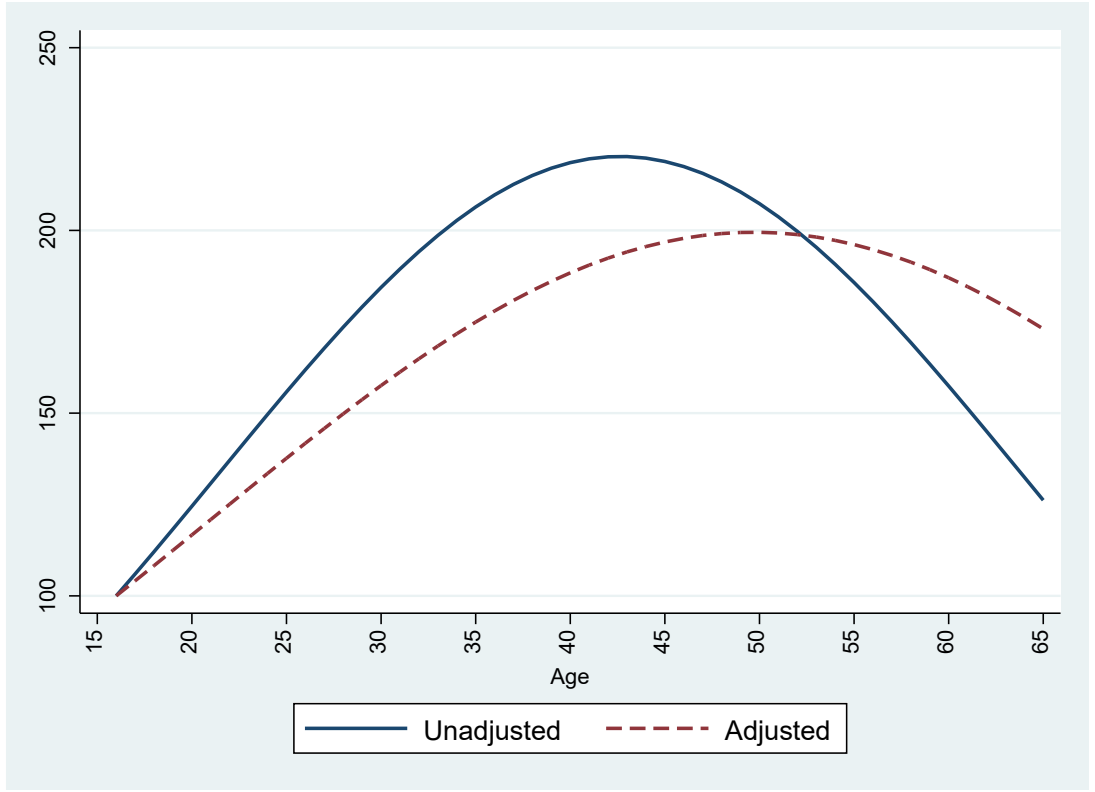

Notes: The unadjusted wage-age profile is drawn by using the coefficients for age and its squared term from the wage equation, without controlling for other variables, using the sample of the full-time workers from the PIAAC data. The adjusted one is constructed after controlling gender, educational levels, literacy skills and worker's job characteristics (i.e., occupation and industry).

Figure 4 Age and Wage Using the PIAAC Data 
In addition, Figure 5 describes the relationship between ICT skills attainment and age. It shows that proficiency scores for ICT skills as well as imputed proficiency scores for ICT skills have a negative linear relationship with age. Older workers in the PIAAC data tend to have lower ICT skills attainment compared to younger ones. This can be also consistent with the exposure to ICT. The shared area in Figure 6 depicts a proportion of adults who had a score for ICT skills, demonstrating a considerable declining trend along with age. Even if we account for missing observations in the ICT skills measure, Figure 5 still shows a negative linear association between imputed ICT skills proficiency scores and age.

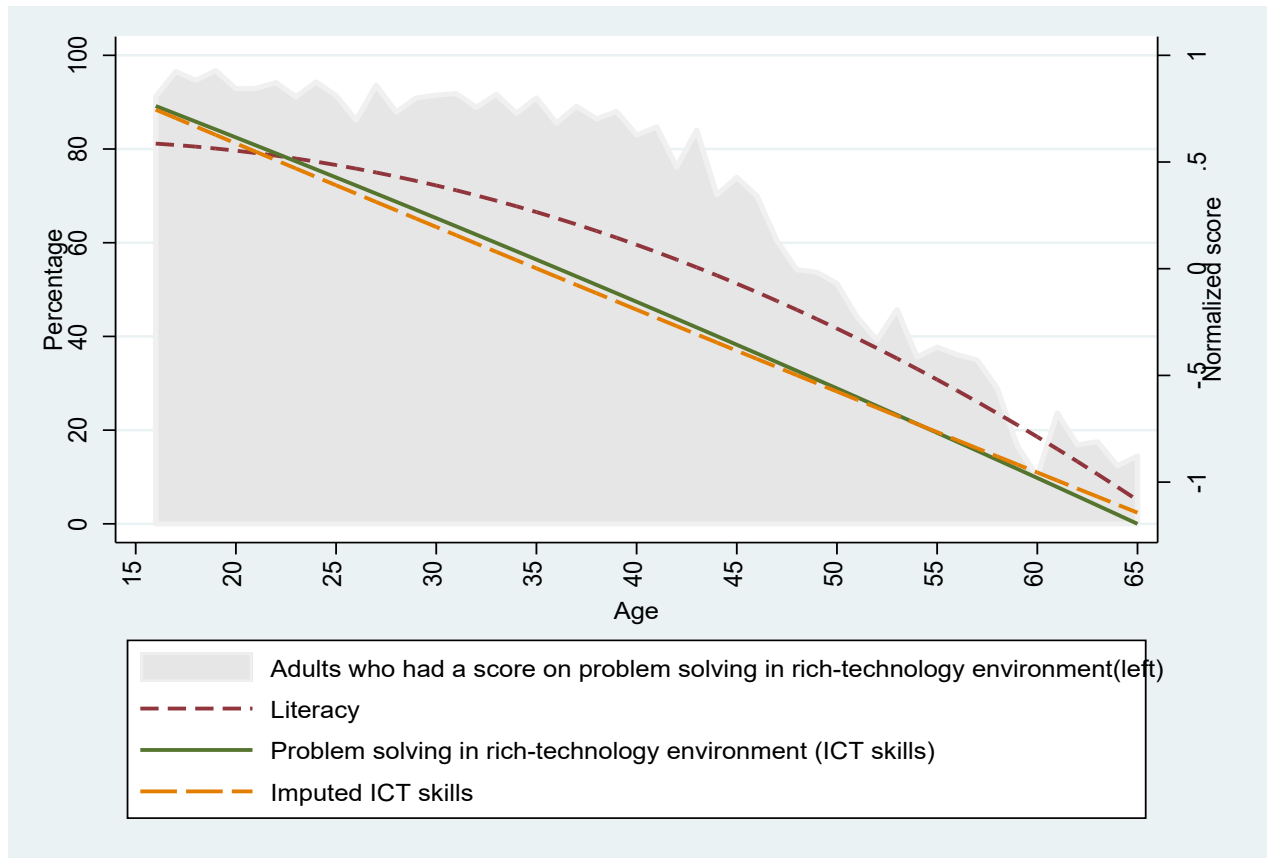

Note: This figure is drawn based on the authors' calculation using the PIAAC sample.

Figure 5 Age and ICT Skills Using the PIAAC Data 


\section{Wage Effect of ICT Skills and Job Training by Age Group}

Table 2 presents estimation results of the Mincer wage equations-Equations (1) and (2). Column (1) reports the estimates of the Mincer equation including ICT skills attainment which is measured in normalized proficiency scores for problem-solving skills in technology-rich environments. Column (2) adds an indicator for job training that takes a value of one if an individual had participated in job-specific, non-formal education within a year prior to the PIAAC survey. In Column (3), a proficiency score for literacy skills is included to account for unobserved abilities (e.g., innate ability), which can cause a bias in the estimation. Column (4) includes ICT skills attainment and its interaction term with age-group dummies from 16-29, 30-49, and 50-65 years as well as an indicator for job-training participation and its interaction term with the agegroup dummies. Column (4) aims to assess whether ICT skills attainment and job training can have relative beneficial effects on the wages of the old workers who are aged 50-65 years. In Column (5), we add literacy skills to Column (4).

In Column (1), the estimates on age and its squared variables are statistically significant and indicates that the effect of age on wages is positive until the worker reaches at the age of 39.6 and then turns negative afterward. Column (1) reports that the effect on the wages of ICT skills is positive and statistically significant. An increase in ICT skills proficiency scores by one standard deviation leads to a wage increase of $3.7 \%$ in Column (1). All other explanatory variables are consistent with those reported in the literature. The female indicator shows that female employees earn, on average, about $20.4 \%$ less than their male counterparts. The returns to schooling increase

over the education levels and the reference group is high school graduates. An additional year of actual labor market experience leads to a wage increase of $2.0 \%$. 


\begin{tabular}{|c|c|c|c|c|c|}
\hline & $(1)$ & $(2)$ & (3) & $(4)$ & $(5)$ \\
\hline Female & $\begin{array}{c}-0.204 * * * \\
(0.026)\end{array}$ & $\begin{array}{c}-0.201 * * * \\
(0.026)\end{array}$ & $\begin{array}{c}-0.201 * * * \\
(0.026)\end{array}$ & $\begin{array}{c}-0.195^{* * *} \\
(0.026)\end{array}$ & $\begin{array}{c}-0.195 * * * \\
(0.026)\end{array}$ \\
\hline HSD & $\begin{array}{c}-0.118 * * \\
(0.047)\end{array}$ & $\begin{array}{c}-0.109 * * \\
(0.047)\end{array}$ & $\begin{array}{c}-0.089^{*} \\
(0.048)\end{array}$ & $\begin{array}{c}-0.113 * * \\
(0.047)\end{array}$ & $\begin{array}{c}-0.097 * * \\
(0.048)\end{array}$ \\
\hline $\mathrm{SMC}$ & $\begin{array}{c}0.199 * * * \\
(0.029)\end{array}$ & $\begin{array}{c}0.180 * * * \\
(0.029)\end{array}$ & $\begin{array}{c}0.182 * * * \\
(0.029)\end{array}$ & $\begin{array}{c}0.181 * * * \\
(0.029)\end{array}$ & $\begin{array}{c}0.182 * * * \\
(0.029)\end{array}$ \\
\hline CLC & $\begin{array}{c}0.367 * * * \\
(0.031)\end{array}$ & $\begin{array}{c}0.337 * * * \\
(0.031)\end{array}$ & $\begin{array}{c}0.328 * * * \\
(0.030)\end{array}$ & $\begin{array}{c}0.336 * * * \\
(0.031)\end{array}$ & $\begin{array}{c}0.324 * * * \\
(0.030)\end{array}$ \\
\hline Labor market experience & $\begin{array}{l}0.020 * * * \\
(0.002)\end{array}$ & $\begin{array}{l}0.019 * * * \\
(0.002)\end{array}$ & $\begin{array}{l}0.019 * * * \\
(0.002)\end{array}$ & $\begin{array}{l}0.019 * * * \\
(0.002)\end{array}$ & $\begin{array}{l}0.019 * * * \\
(0.002)\end{array}$ \\
\hline AGE & $\begin{array}{c}0.050 * * * \\
(0.007)\end{array}$ & $\begin{array}{c}0.050 * * * \\
(0.007)\end{array}$ & $\begin{array}{c}0.046^{* * *} \\
(0.007)\end{array}$ & $\begin{array}{c}0.053 * * * \\
(0.012)\end{array}$ & $\begin{array}{c}0.051 * * * \\
(0.012)\end{array}$ \\
\hline $\mathrm{AGE}^{\wedge} 2 / 100$ & $\begin{array}{c}-0.063^{* * *} \\
(0.009)\end{array}$ & $\begin{array}{c}-0.062 * * * \\
(0.009)\end{array}$ & $\begin{array}{c}-0.058 * * * \\
(0.009)\end{array}$ & $\begin{array}{c}-0.068 * * * \\
(0.015)\end{array}$ & $\begin{array}{c}-0.067 * * * \\
(0.015)\end{array}$ \\
\hline 30-49 Age group & & & & $\begin{array}{l}-0.031 \\
(0.056)\end{array}$ & $\begin{array}{l}-0.034 \\
(0.056)\end{array}$ \\
\hline 50-65 Age group & & & & $\begin{array}{c}0.007 \\
(0.097)\end{array}$ & $\begin{array}{c}0.001 \\
(0.097)\end{array}$ \\
\hline Indicator of ICT Skills Obs & $\begin{array}{c}-0.140 * * * \\
(0.029)\end{array}$ & $\begin{array}{c}-0.127 * * * \\
(0.029)\end{array}$ & $\begin{array}{c}-0.104 * * * \\
(0.029)\end{array}$ & $\begin{array}{c}-0.127 * * * \\
(0.029)\end{array}$ & $\begin{array}{c}-0.103 * * * \\
(0.029)\end{array}$ \\
\hline ICT Skills & $\begin{array}{c}0.037 * * * \\
(0.013)\end{array}$ & $\begin{array}{c}0.033 * * \\
(0.013)\end{array}$ & $\begin{array}{c}-0.044 * * \\
(0.022)\end{array}$ & $\begin{array}{c}0.029 \\
(0.023)\end{array}$ & $\begin{array}{l}-0.045 \\
(0.028)\end{array}$ \\
\hline ICT Skills x 30-49 Age group & & & & $\begin{array}{c}0.016 \\
(0.027)\end{array}$ & $\begin{array}{c}0.011 \\
(0.027)\end{array}$ \\
\hline ICT Skills x 50-65 Age group & & & & $\begin{array}{l}-0.016 \\
(0.037)\end{array}$ & $\begin{array}{l}-0.035 \\
(0.037)\end{array}$ \\
\hline Job Training & & $\begin{array}{l}0.138 * * * \\
(0.022)\end{array}$ & $\begin{array}{l}0.132 * * * \\
(0.022)\end{array}$ & $\begin{array}{c}0.053 \\
(0.044)\end{array}$ & $\begin{array}{c}0.050 \\
(0.044)\end{array}$ \\
\hline Job Training x 30-49 Age group & & & & $\begin{array}{l}0.094 * \\
(0.050)\end{array}$ & $\begin{array}{l}0.087^{*} \\
(0.050)\end{array}$ \\
\hline Job Training x 50-65 Age group & & & & $\begin{array}{c}0.150 * * \\
(0.069)\end{array}$ & $\begin{array}{c}0.150 * * \\
(0.069)\end{array}$ \\
\hline LITERACY & & & $\begin{array}{c}0.101 * * * \\
(0.024)\end{array}$ & & $\begin{array}{c}0.106 * * * \\
(0.024)\end{array}$ \\
\hline Constant & $\begin{array}{c}8.139 * * * \\
(0.152)\end{array}$ & $\begin{array}{c}8.074 * * * \\
(0.154)\end{array}$ & $\begin{array}{c}8.138 * * * \\
(0.156)\end{array}$ & $\begin{array}{c}8.087 * * * \\
(0.221)\end{array}$ & $\begin{array}{c}8.114 * * * \\
(0.223)\end{array}$ \\
\hline $\begin{array}{l}\text { Occupation and Industry Fixed } \\
\text { Effects }\end{array}$ & Yes & Yes & Yes & Yes & Yes \\
\hline R-Square & 0.406 & 0.414 & 0.418 & 0.417 & 0.421 \\
\hline Observations no. & 2715 & 2710 & 2710 & 2710 & 2710 \\
\hline
\end{tabular}

Notes: The dependent variable is the log of hourly earnings. The sample consists of full-time workers aged 16-65 who work at least 30 hours per week. Robust Standard errors are in parentheses. The missing proportion is $25.6 \%$. ${ }^{*} p<0.1,{ }^{* *} p<0.05,{ }^{* * *} p<0.01$.

Table 2 Wage Equation with Aging and ICT Skills 
Column (2) has the estimates of the basic Mincer wage regression with ICT skills and an indicator for job training participation. The estimate on ICT skills is positive and statistically significant. The estimated coefficient on job training of 0.138 indicates that workers who had participated in non-formal, job-related education during the previous year earn, on average, about $13.8 \%$ more than the non-participants with the same levels of age, labor market experience, education, and ICT skills. Columns (1) and (2) provide supporting evidence that, on average, ICT skills attainment and job-training participation can have beneficial effects on a worker's productivity.

However, the estimates on ICT skills attainment and job training can be biased due to the endogeneity sourced from unobserved abilities. For instance, if workers with a higher level of innate ability are more likely to accept job training or ICT-related education, the effects of both ICT skills attainment and job training would be overestimated. Column (3) reports the estimation results when controlling for the unobserved innate ability by adding literacy skills proficiency scores as its proxy in the empirical model. The estimated coefficient for job training of 0.132 , which is not just positive and statistically significant, is almost identical to the estimate without literacy as additional control variable. This implies that whether an individual had participated in job training or not is not significantly correlated with the unobserved ability as long as literacy skills proficiency is its good proxy. Hence, job training participation has a positive wage effect independently from worker's ability. On the other hand, the estimate on ICT skills dramatically changes as we add a measure of literacy skills as an additional control variable. The wage effect of ICT skills attainment turns negative and statistically significant at the 5\% level. This implies that ICT skills is highly correlated with literacy skills (or unobserved ability). If literacy skill is 
omitted, the effect of literacy skills is captured by that of ICT skills. In other words, the estimated effect without literacy skills can be biased as ICT skills simply captures the effect of unobserved innate ability. As confirmed in the correlation analysis, ICT skills are highly correlated with literacy skills. Also, literacy was used as one of the important predictors for missing ICT skills in the imputation model.

It is important to note that this study is more focused on investigating the relative effects that the older workers, aged 50-65 years can have from ICT skills attainment, rather than exploring its average wage effects. Thus, we restrain our attention on whether ICT skills attainment has any significant impact on the productivity or the wages of older workers, even after controlling literacy skills.

Column (4) reports the estimates for ICT skills and its interactions with different age groups and those for an indicator for job training and its interactions with different age groups. Returns to ICT skills are positive but statistically insignificant. The estimates for the interaction term between ICT skills and age-group dummies are also statistically insignificant, suggesting that the effects on the wages of ICT skills attainment do not vary across age groups. In contrast, the estimates for the interaction term between the job training participation indicator and age-group dummies are positive and statistically significant, suggesting that the wage effects of job training increase with age. As shown in Column (4), for a worker in the age group of 30-49, the return to job training is 9.4 percentage points greater than the reference group - that is the young workers group. This indicates that when the workers who are aged 30-49 years have received job-related training at least once during the year, their wages are higher by 9.4 percentage points compared to those who are aged 16-29 years and participated in job-related training. The strongest effect of job training on wage is captured for the workers aged 50-65. In this age group, workers who received 
job-related training earned 15.0 percentage points more than those who are aged 16-29 years and received job-related training.

Column (5) includes proficiency scores for literacy skills as a proxy for the innate ability to control the unobserved innate ability that is closely correlated with ICT skills proficiency level as well as wages. Column (5) shows that the results remain consistent even after adding the literacy skills proficiency scores to Column (4). For the older workers who were aged 50-64, the wage effect of their ICT skills attainment is negative, but statistically insignificant, whereas that of job training appears larger than any other age groups.

Figure 6(a) presents the graphically relative productivity of older workers aged 50-65, which is drawn based on Column (4) of Table 2. The older workers aged 50-65 at the mean values of the ICT skills and job training participation earn 8.6 percentage points $\left(\gamma_{I C T}+\right.$ $\left.\gamma_{I C T, A G E} \times \overline{I C T_{\text {skills }_{j}}}+\gamma_{T, A G E} \times \overline{\text { Training }_{j}}=0.086\right)$ more in wages than the younger workers aged 16-29, who are the reference group in this specification. ${ }^{6}$ Figure 6(a) also shows that the older workers cannot enjoy additional wage gains from acquiring a higher level of ICT skills. The relative wage gain that the older workers obtain becomes smaller with a higher level of ICT skills, implying that there is no complementary effect between older workers and ICT skills.

\footnotetext{
${ }^{6}$ Note that most of these relative gains the older workers earn compared to the younger workers are sourced from the wage effects of job training. The estimation result reports that the net wage effect of ICT skills attainment for the older workers is marginal.
} 


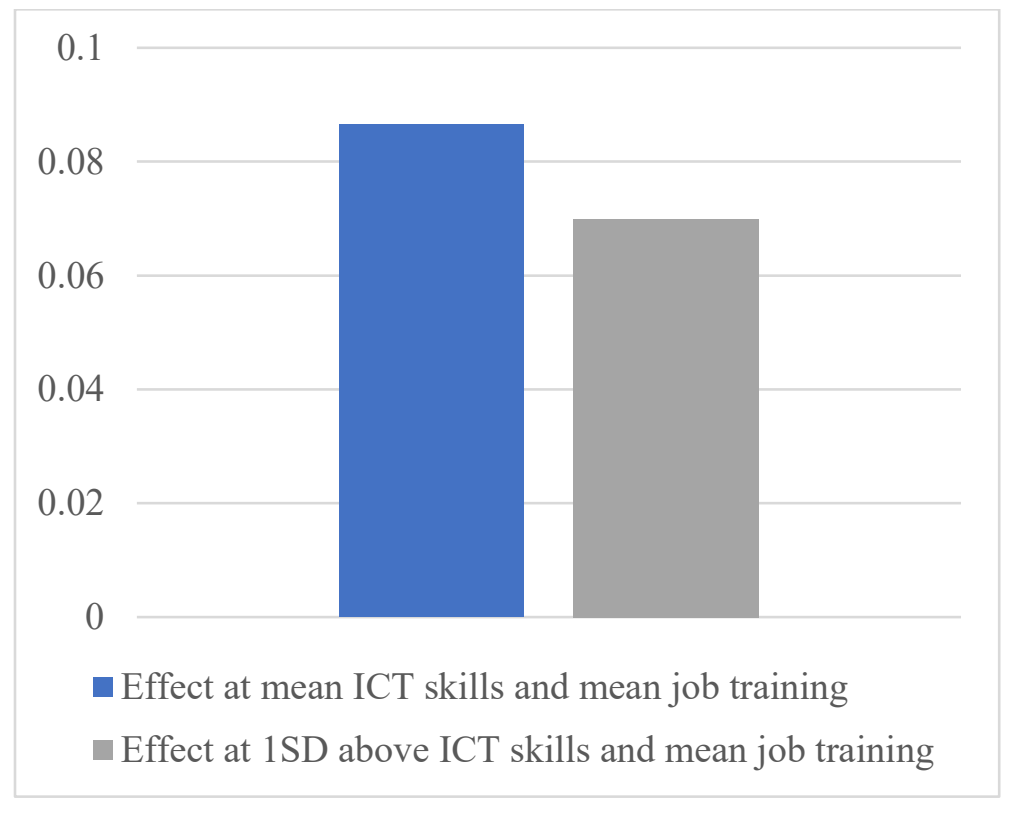

a) Effect of Workers Aged 50-65 on Wages

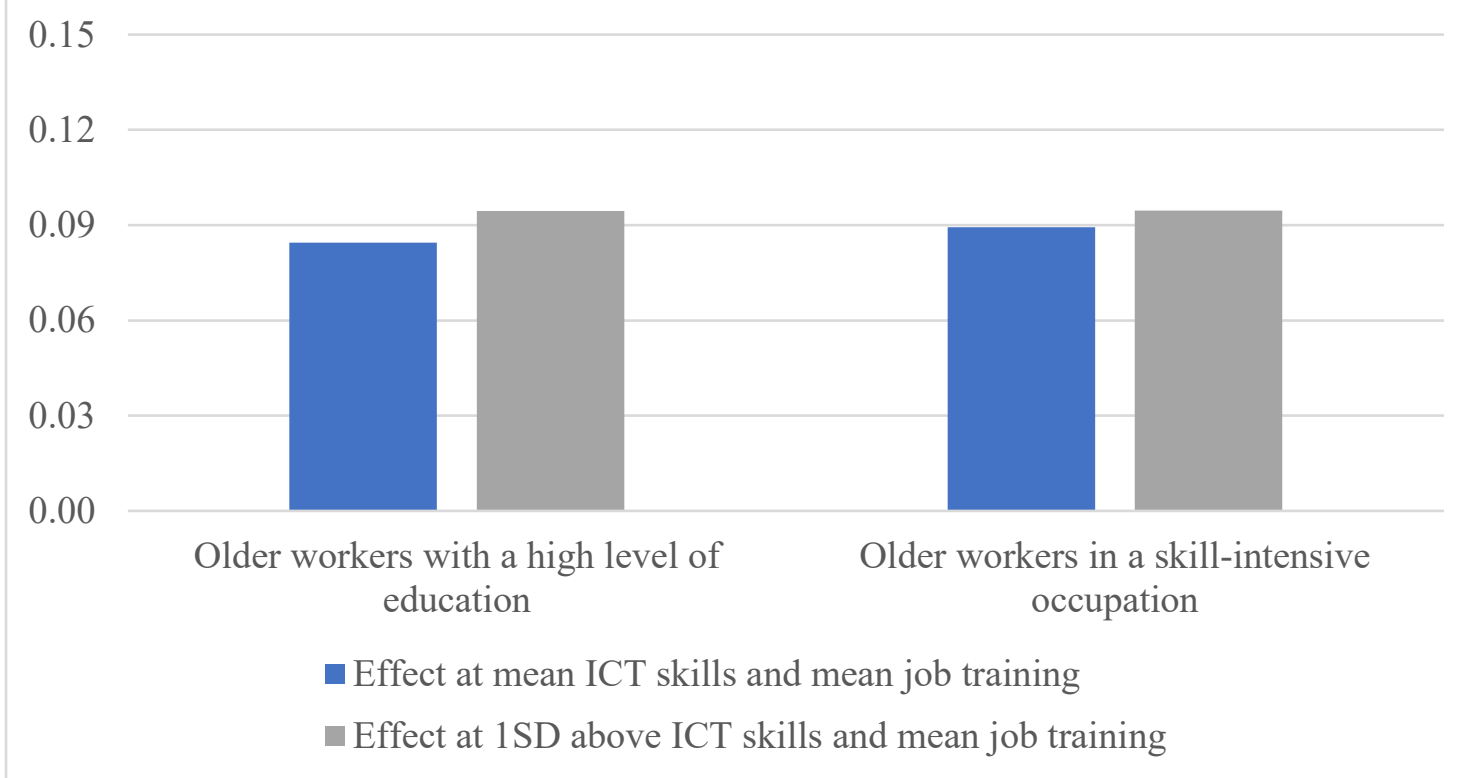

b) Effect of Workers Aged 50-65 with a High Level of Education or in a Skill-intensive Occupation on Wages

Notes: The effects in (a) are drawn based on the estimates in Column (4) of Table 2. The estimates in Columns (1) and (2) of Table 3 are used to illustrate the effects in (b), respectively. The figures show the productivity gain of the workers aged 50-65 years relative to those aged 15-29 years.

Figure 6 Impact of Aging on Wage 
We examine whether the effects of ICT skills on the productivity of older workers differs by education and skill levels. Therefore, we estimate Equation (3), which adds two distinct interaction terms — one between ICT skills, age-group dummies, and an indicator for having a high level of education, and the other between ICT skills, age-group dummies, and an indicator for employing in a skill-intensive occupation. By estimating this specification, we can identify who will receive greater benefits from higher level of ICT skills attainment among the different subgroups of the older workers.

The estimation results are reported in Table 3. In Column (1), an interaction term between ICT skills, age-group dummies, and an indicator for receiving a high level of education are included. Column (2) has the interaction term between ICT skills, age-group dummies, and an indicator for employing in a skill-intensive occupation. Column (3) includes both interaction terms. In all of the specifications, we add literacy skills proficiency scores for controlling the (unobserved) innate ability, and occupation and industry fixed effects. As in the previous wage equations, Table 3 reports that most of the explanatory variables including age and its squared term, gender, educational levels, and labor market experience are statistically significant, and their estimated parameters have the expected signs.

In Column (1), we add an interaction term between ICT skills, age-group dummies, and an indicator for an individual who received at least a college education. The estimated coefficient for the interaction term between ICT skills, the 50-65 age group, and an indicator for attaining a high level of education is estimated to be around 0.118 , positive and statistically significant. It indicates that along with the one standard deviation (1SD) increase in ICT skills, highly educated workers in the age range of 50-65 obtain relative wage gains by 11.8 percentage points compared to loweducated workers in the same age group. 


\begin{tabular}{|c|c|c|}
\hline & (1) & $(2)$ \\
\hline Female & $\begin{array}{c}-0.193^{* * *} \\
(0.026)\end{array}$ & $\begin{array}{c}-0.197^{* * *} \\
(0.026)\end{array}$ \\
\hline HSD & $\begin{array}{c}-0.116^{* *} \\
(0.050)\end{array}$ & $\begin{array}{c}-0.110^{* *} \\
(0.049)\end{array}$ \\
\hline SMC & $\begin{array}{c}0.198^{* * *} \\
(0.029)\end{array}$ & $\begin{array}{c}0.178^{* * *} \\
(0.029)\end{array}$ \\
\hline CLC & $\begin{array}{c}0.329^{* * *} \\
(0.030)\end{array}$ & $\begin{array}{c}0.316^{* * *} \\
(0.030)\end{array}$ \\
\hline Labor market experience & $\begin{array}{c}0.019^{* * *} \\
(0.002)\end{array}$ & $\begin{array}{c}0.019^{* * *} \\
(0.002)\end{array}$ \\
\hline AGE & $\begin{array}{c}0.050^{* * *} \\
(0.012)\end{array}$ & $\begin{array}{c}0.049^{* * *} \\
(0.012)\end{array}$ \\
\hline $\mathrm{AGE}^{\wedge} 2 / 100$ & $\begin{array}{c}-0.064^{* * *} \\
(0.015)\end{array}$ & $\begin{array}{c}-0.063^{* * *} \\
(0.015)\end{array}$ \\
\hline 30-49 Age group & $\begin{array}{c}-0.059 \\
(0.057)\end{array}$ & $\begin{array}{l}-0.040 \\
(0.056)\end{array}$ \\
\hline 50-65 Age group & $\begin{array}{l}-0.034 \\
(0.101)\end{array}$ & $\begin{array}{l}-0.027 \\
(0.099)\end{array}$ \\
\hline Indicator of ICT Skills Obs & $\begin{array}{c}-0.099^{* * *} \\
(0.029)\end{array}$ & $\begin{array}{c}-0.103^{* * *} \\
(0.029)\end{array}$ \\
\hline ICT Skills & $\begin{array}{c}-0.058^{* *} \\
(0.029)\end{array}$ & $\begin{array}{l}-0.054^{*} \\
(0.028)\end{array}$ \\
\hline ICT Skills x 30-49 Age group & $\begin{array}{l}-0.037 \\
(0.031)\end{array}$ & $\begin{array}{l}-0.008 \\
(0.032)\end{array}$ \\
\hline ICT Skills x 50-65 Age group & $\begin{array}{l}-0.066 \\
(0.043)\end{array}$ & $\begin{array}{l}-0.098^{* *} \\
(0.045)\end{array}$ \\
\hline ICT Skills x 30-49 Age group x High Educ & $\begin{array}{l}0.100^{* * *} \\
(0.031)\end{array}$ & \\
\hline ICT Skills x 50-65 Age group x High Educ & $\begin{array}{l}0.118^{* *} \\
(0.060)\end{array}$ & \\
\hline ICT Skills x 30-49 Age group x Skill Occ & & $\begin{array}{c}0.030 \\
(0.030)\end{array}$ \\
\hline ICT Skills x 50-65 Age group x Skill Occ & & $\begin{array}{l}0.136^{* * *} \\
(0.044)\end{array}$ \\
\hline Job Training & $\begin{array}{c}0.047 \\
(0.044)\end{array}$ & $\begin{array}{c}0.050 \\
(0.044)\end{array}$ \\
\hline Job Training x 30-49 Age group & $\begin{array}{c}0.091^{*} \\
(0.050)\end{array}$ & $\begin{array}{c}0.085^{*} \\
(0.050)\end{array}$ \\
\hline Job Training x 50-65 Age group & $\begin{array}{l}0.164^{* *} \\
(0.071)\end{array}$ & $\begin{array}{l}0.166^{* *} \\
(0.070)\end{array}$ \\
\hline LITERACY & $\begin{array}{l}0.122^{* * *} \\
(0.025)\end{array}$ & $\begin{array}{l}0.115^{* * *} \\
(0.024)\end{array}$ \\
\hline Constant & $\begin{array}{c}8.127^{* * *} \\
(0.227)\end{array}$ & $\begin{array}{c}8.159^{* * *} \\
(0.226)\end{array}$ \\
\hline
\end{tabular}




\begin{tabular}{lcc}
\hline R-Square & 0.424 & 0.424 \\
Observations no. & 2710 & 2710
\end{tabular}

Notes: The dependent variable is the log of hourly earnings. The sample consists of full-time workers aged 16-65 who work at least 30 hours per week. Robust Standard errors are in parentheses. The missing proportion is $25.6 \%{ }^{*} p<0.1,{ }^{* *} p<0.05,{ }^{* * *} p<0.01$

Table 3 Wage Equation for Aging, Education, Occupation, and ICT Skills

In Column (2), we add an interaction term between ICT skills, age-group dummies, and an indicator for whether an individual is employed in a skill-intensive occupation. The coefficient for the interaction term between ICT skills, the 50-65 age group and an indicator for being employed in a skill-intensive occupation of 0.136 is positive and statistically significant. With the $1 \mathrm{SD}$ increase in ICT skills, the wages that workers who are aged 50-65 years and are employed in a skill-intensive occupation gain are higher by 13.6 percentage points compared to those in the same age group but holding a non-skill-intensive occupation.

In contrast to those in Table 2, where we find no heterogeneous ICT skills effects by age groups, the results in Table 3 identify who can benefit from acquisition of a higher level of ICT skills among the older workers. The results in Table 3 suggest that older high-skilled workers, such as those who are well-educated or hold a skill-intensive occupation can enjoy relative wage gains from attainment of a higher level of ICT skills, compared to older low-skilled workers.

Figure 6(b) illustrates productivity of those older workers who are in the age range of 5065 and are at least college-educated or employed in a skill-intensive occupation relative to that of younger workers who are aged 15-29 years. This is drawn from Columns (1) and (2) of Table 3, respectively. The productivity of these groups of older workers is significantly positive at the mean values of the ICT skills and job-training participation. The estimated effect of $0.084\left(\gamma_{A G E}+\right.$ $\left.\gamma_{I C T, A G E} \times \overline{I C T_{S K I L L_{J}}}+\gamma_{I C T, A G E, H i g h} \times \overline{I C T_{S K I L L_{J}} * H i g h_{E d u_{J}}}+\gamma_{T, A G E} \times \overline{\operatorname{Tralning~}_{J}}=0.084\right)$ 
indicates that they have higher productivity by 8.4 percentage points, compared to younger workers. Older workers in a skill-intensive occupation are estimated to have higher productivity by 8.9 percentage points, relative to that of younger workers $\left(\gamma_{A G E}+\gamma_{I C T, A G E} \times \overline{I C T_{-} S K I L L_{j}}+\right.$ $\left.\gamma_{I C T, A G E, H i g h} \times \overline{I C T_{-} S K I L L_{j} * S_{\text {Skill_OCC }}}+\gamma_{T, A G E} \times \overline{\text { Training }_{j}}=0.089\right) . \quad$ Figure $6(\mathrm{~b})$ also illustrates that ICT skills attainment has significantly positive additional effects on the productivity of older workers who are highly educated or employed in a skill-intensive occupation. If older workers with a high level of education or in a skill-intensive occupation possess higher scores of ICT skills attainment by $1 \mathrm{SD}$, their relative productivity to younger workers would increase to about 9.5 percentage points. This implies that there is a complementary effect between ICT skills and older workers, when the older workers are skilled.

\section{Discussion}

In this section, we discuss how we have attempted to address the sources of endogeneity bias sourced from omitted variable bias, missing data problems, and self-selection in estimating the Mincer-type equations. As previously mentioned, we attempt to control for omitted variable bias. As for the omitted variable bias, we assume that there is an innate ability that may affect ICT skills attainment and worker's wages and use literacy scores as a measure for the innate ability when estimating Equations (1) through (3).

Another major endogeneity bias comes from missing data. As already mentioned, ICT skills measure are available only for those individuals who took the computer-based assessment. In our sample, the proportion of the individuals without ICT skills measure accounts for $25.6 \%$. The individuals with missing data are not random; thus, we account for the missing data problem with an imputation method. In the estimation of imputation models, we use a regression imputation 
where literacy and numeracy test scores are adopted as the main variables to predict missing ICT skills measure. In addition to the imputation method, following Busso, DiNardo, and McCrary (2014), we adopt an IPW to control for the missing data problem. This is a commonly used method, and it is used to adjust for unequal sampling fractions in sample surveys. We first use a logit model to predict the probability to take the computer-based assessment and have ICT skills proficiency scores in the PIAAC survey using the respondent's individual characteristics and background variables (gender, education levels, work experience, mother's education, participation in job training, literacy, industry, and occupation). Accordingly, we use this probability as a (inverse) weight in estimating the Mincer equation. The estimation results using an IPW are reported in Appendix A (Table 1) and Appendix B (Table 2) and are somewhat similar to those in Tables 2 and 3. Figure 7(a) graphically illustrates the relative productivity of older workers from the ages 50-65, drawn based on Column (4) of Appendix A (Table 1). It shows that older workers at the mean values of the ICT skills and job training participation earn 9.9 percentage points more in wages than the younger workers, and this relative wage effect is larger than that in Figure 6(a). Similar to Figure 6(a), Figure 7(a) also does not provide evidence for a complementary effect between ICT skills and older workers, suggesting that ICT skills attainment does not have positive additional effects on the productivity of older workers. Figure 7(b) illustrates the productivity of older workers who are at least college-educated or employed in a skill-intensive occupation relative to that of younger workers, drawn from Columns (1) and (2) of Table 3, respectively. It shows that the productivity of older worker with a high level of education or in a skill-intensive occupation is positive at the mean values of ICT skills and job training, and the values are larger than that in Figure 6(b). As in Figure 6(b), Figure 7(b) also provides evidence that there is a complementary effect between older high-skilled workers and ICT skills attainment. 


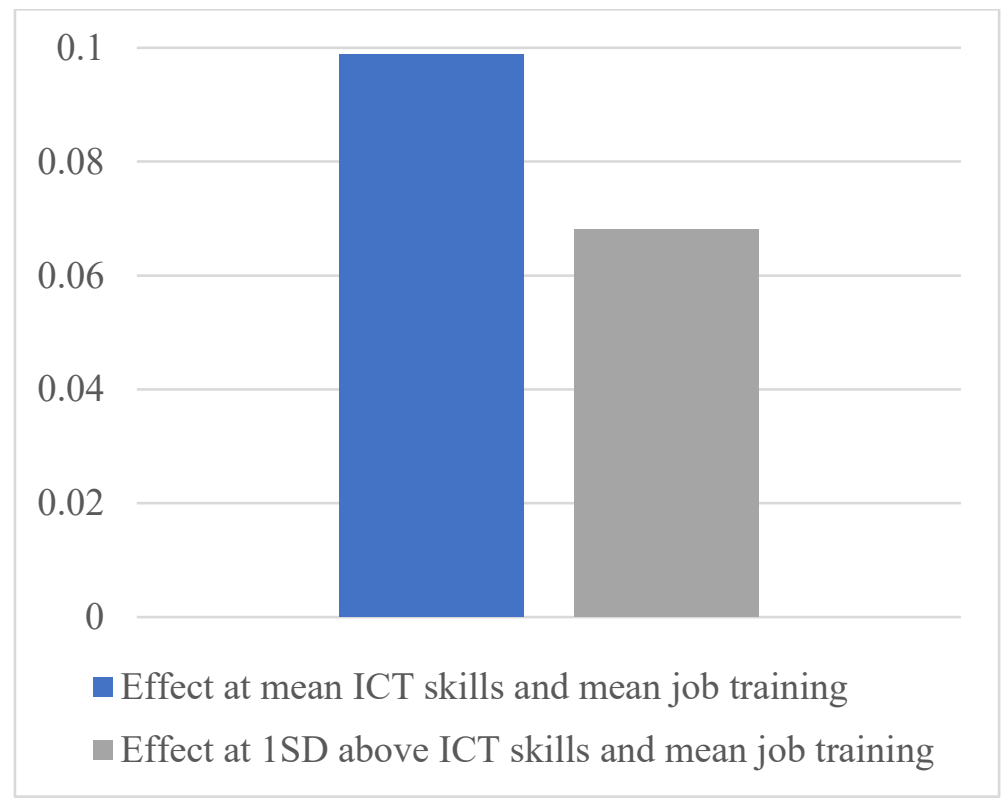

a) Effect of Workers Aged 50-65 on Wages

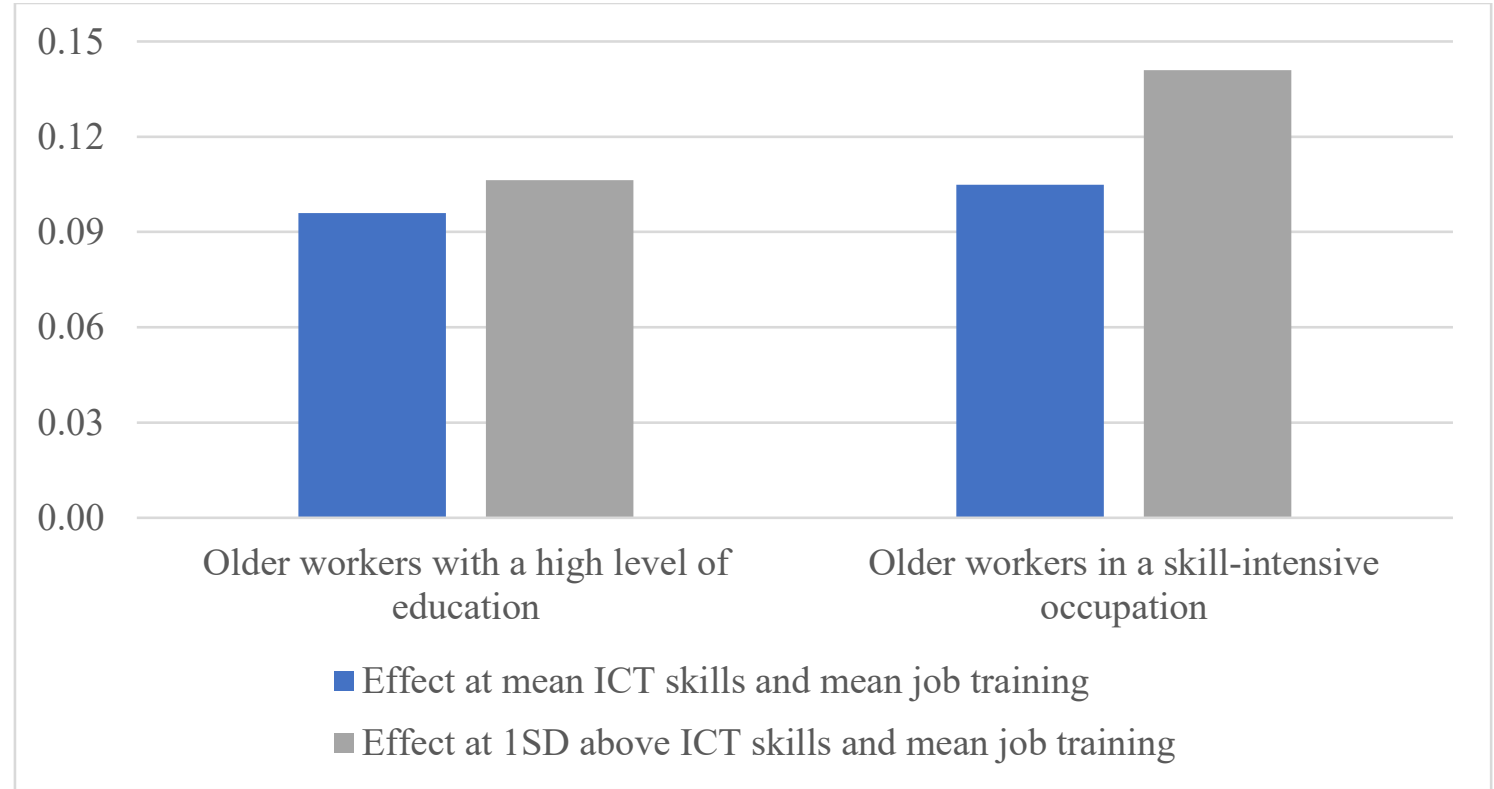

b) Effect of Workers Aged 50-65 with a High Level of Education or in a Skill-intensive Occupation on Wages

Notes: The effects in (a) are drawn based on the estimates in Column (4) of Table A. The estimates in Columns (1) and (2) of Table B are used to illustrate the effects in (b), respectively. The figures show the productivity gain of the workers aged 50-65 years relative to those aged 15-29 years.

Figure 7 Impact of Aging on Wage, using Inverse Probability Weight (IPW) 
In line with the missing data problem, the other major source of endogeneity bias is selfselection in achieving ICT skills attainment and/or participating in job training. As previously mentioned, ICT skills attainment and participation in job training are not randomly determined. For instance, an individual who expects to have a higher wage through ICT skills attainment and participation in job-related training is more likely to attain ICT skills and/or join job-related training courses. To deal with this self-selection issue, we have attempted several econometric techniques including instrument variable methodology, difference-in-difference, and propensity score matching.

We find that it is extremely difficult to come up with appropriate instruments for ICT skills and/or job training. Falck, Heimisch-Roecker and Wiederhold (2020) who estimate the returns to ICT skills across 19 countries and across German regions use (regional) variation in the extent of the traditional voice-telephony network, which existed before the introduction of broadband across countries and German municipalities as an instrument for ICT skills. This instrument variable may not be appropriate in the case of Korea where the roll-out of broadband network is not determined by the traditional voice-telephony network but by the government intervention. A possible instrument is the presence of computer at home during childhood, but this data is not available in the PIAAC survey. As mentioned in Introduction, the implementation of "Computer" courses at schools over the period, 2001-2005 is one of the Korean government's efforts to increase ICT literacy and familiarize students and people with ICTs. We attempt to adopt difference-in-difference methodology where receiving ICT education at schools is the treatment assignment. Thus, we are to compare the cohorts who learned how to use computer at schools with those who had no opportunities. However, the identification strategy does not work because there is no distinction between the cohorts and age groups. Hence, instead of controlling unobservable 
variables, we attempt to control observable variables using the propensity score and estimate the role of ICT skills on wages across age cohorts. Unfortunately, the results re somewhat sensitive.

As for participation in job training, distance to job training center and availability of training facilities might be a possible instrument for participation in job training. As noted in Lee, Han and Song (2019), regional dummies for availability of training facilities turn out to be a weak instrument, and the results are not quantitatively sensitive to the endogeneity issue. We leave thorough investigation of the endogeneity issues for future studies.

\section{Conclusion}

This paper assessed the effects of aging on labor productivity, using the individual workerlevel data. We found that ICT skills attainment can have significantly positive effects on the productivity of older workers who are highly educated or employed in skill-intensive occupations. To be specific, the estimation results showed that the wage effects of ICT skills attainment are greater for those with a high level of education or in a skill-intensive occupation among older workers. We also found that older workers can obtain significant benefits from job training, relative to the younger workers. The estimation results also show that even compared to younger workers, the older skilled workers can be more productive through higher ICT skills attainment and job training participation. These results suggest that productivity decline due to the aging process can be mitigated by promoting training for older workers to equip them with adequate ICT skills, even with a larger productivity than the younger workers.

Our findings suggest that Korea's rapid demographic shift toward an aged society is not a mere threat to its economy but offers an opportunity to utilize more-mature workers' skills in productive ways with the support of technologies and lifelong education. Firms' investment in ICT 
technologies and training of ICT skills can help improve productivity and extend the working age of aging populations.

Our empirical investigations are subject to several limitations. We had to use a worker's proficiency in problem solving in technology-rich environment test as a measure of ICT skills. These variables may not be perfect measures of and ICT skills. In addition, as previously discussed, we have attempted to address the major endogeneity issues using different empirical techniques such as inclusion of fixed effects, inclusion of literacy skills scores, adoption of regression imputation and IPW methods, and found that the results were robust. However, these techniques may not fully control for the potential endogeneity problems. The use of valid instrumental variables and the implementation of experimental settings to control for endogeneity in the ICT skills attainment and job training participation would provide consistent estimates, but the ideal instruments are hard to find. We leave this issue for future studies. 


\section{References}

Acemoglu, D. (2009). Introduction to modern economic growth. Princeton University.

Almeida, R. K., \& Faria, M. (2014). The wage returns to on-the-job training: Evidence from matched employer-employee data. IZA Journal of Labor \& Development, 3(1), 19.

Asian Development Bank (2018). Tapping technology to maximize the longevity dividend in Asia. Manila: ADB.

Bassanini, A., Booth, A., Brunello, G., De Paola, M., \& Leuven, E. (2005). Workplace training in Europe (Working Paper No. 1640). The Institute for the Study of Labor (IZA).

Belloni, M., \& Villosio, C. (2015). Training and wages of older workers in Europe. European Journal of Ageing, 12(1), 7-16.

Berg, P. B., Hamman, M. K., Piszczek, M. M., \& Ruhm, C. J. (2017). The relationship between employer-provided training and the retention of older workers: Evidence from Germany. International Labor Review, 156(3-4), 495-523.

Borsch-Supan, A., \& Weiss, M. (2016). Productivity and age: Evidence from work teams at the assembly line. The Journal of the Economics of Ageing, 7, 30-42.

Burtless, G., (2013). The impact of population aging and delayed retirement on workforce productivity (Working paper 2013-11). Center for Retirement Research.

Busso, M., DiNardo, J., \& McCrary, J. (2014). New evidence on the finite sample properties of propensity score reweighting and matching estimators. Review of Economics and Statistics, 96(5), 885-897. 
Cegolon, A. (2015). Determinants and learning effects of adult education-training: A crossnational comparison using PIAAC data (Working Paper No. 15-11). Department of Quantitative Social Science-UCL Institute of Education, University College London.

Chomik, R., \& Piggott, J. (2019). Demographic and technological change: Two megatrends shaping the labour market in Asia (Working Paper 2010/11). ARC Centre of Excellence in Population Ageing Research.

Dostie, B., \& Léger, P. T. (2014). Firm-sponsored classroom training: Is it worth it for older workers? Canadian Public Policy, 40(4), 377-390.

Falck, O., Heimisch-Roecker, A., \& Wiederhold, S. (2020). Returns to ICT skills. Research Policy, Article 104064.

Faun, S., \& Moreau, Y. (2018). Managing tomorrow's digital skills-What conclusions can we draw from international comparative indicators? Paris: UNESCO.

Göbel, C., \& Zwick, T. (2013). Are personnel measures effective in increasing productivity of old workers? Labor Economics, 22, 80-93.

Goux, D., \& Maurin, E. (2000). Returns to firm-provided training: Evidence from French workerfirm matched data. Labor economics, 7(1), 1-19.

Heckman, J., Lochner, L., \& Todd, P. (2003). Fifty years of mincer earnings regressions (NBER Working Paper No. 9732). National Bureau of Economic Research.

Haelermans, C., \& Borghans, L. (2012). Wage effects of on-the-job training: A metaanalysis. British Journal of Industrial Relations, 50(3), 502-528.

Ministry of Education (MoE) \& Korea Education and Research Information Service (KERIS) (2014). White paper on ICT in education Korea 2014. Seoul, Korea: KERIS. 
Korea Research Institute for Vocational Education and Training (KRIVET). (2012). Programme for the international assessment of adult competencies, PIAAC 2013 [in Korean]. Seoul, Korea: KRIVET.

Lang, J. (2012). The aims of lifelong learning: Age-related effects of training on wages and job security. SOEP papers on multidisciplinary panel data research. DIW Berlin, 478.

Lee, J. W., Han, J. S., \& Song, E. (2019). The effects and challenges of vocational training in Korea. International Journal of Training Research, 17(sup1), 96-111.

Lee, J.W., Song, E., \& Kwak, D. (2020). Aging labor, ICT capital, and productivity in Japan and Korea. Journal of Japanese and International Economies, 58.

Little, R. \& Rubin, D. (2002). Statistical analysis with missing data. J. Wiley and Sons.

Meyer, J. (2011). Workforce age and technology adoption in small and medium-sized service firms. Small Business Economics, 37(3), 305-324.

Organization for Economic Co-operation and Development. (2013a). OECD skills outlook 2013. Paris: OECD.

Organization for Economic Co-operation and Development. (2013b). The survey of adults skills: Reader's companion. Paris: OECD .

Pfeifer, C., \& Wagner, J. (2014). Is innovative firm behavior correlated with age and gender composition of the workforce? Evidence from a new type of data for German enterprises. Journal for Labour Market Research, 47(3), 223-231.

Picchio, M., \& Van Ours, J. C. (2013). Retaining through training even for older workers. Economics of Education Review, 32, 29-48.

Pischke, J. S. (2001). Continuous training in Germany. Journal of population economics, 14(3), 523-548. 
Rubin, D. (1987). Semiparametric theory and missing data. J. Wiley and Sons.

Schubert, T., \& Andersson, M. (2015). Old is gold? The effects of employee age on innovation and the moderating effects of employment turnover. Economics of Innovation and New Technology, 24(1-2), 95-113.

Truxillo, D. M., Cadiz, D. M., \& Hammer, L. B. (2015). Supporting the aging workforce: A review and recommendations for workplace intervention research. Annual Review of Organizational Psychology and Organizational Behavior, 2(1), 351-381.

Yoo, G., \& Kang, C. (2010). The impacts of vocational training on earnings in Korea: Evidence from the economically active population survey. KDI Journal of Economic Policy, 32(2), $29-53$.

United Nations. (2019, August 16). World population prospects: The 2019 revision. https://population.un.org/wpp/

Vogel, E., Alexander L. \& Borsch-Supan, A. (2017). Aging and pension reform: Extending the retirement age and human capital formation. Journal of Pension Economics \& Finance, 16, $81-107$.

Weinberg, B. (2004) Experience and technology adoption (IZA Discussion Paper No. 1051).

World Bank. (2016). World development report 2016: Digital dividends. World Bank. 


\begin{tabular}{|c|c|c|c|c|c|}
\hline & $(1)$ & $(2)$ & (3) & $(4)$ & $(5)$ \\
\hline \multirow[t]{2}{*}{ Female } & $-0.197^{* * *}$ & $-0.197^{* * *}$ & $-0.197^{* * *}$ & $-0.192^{* * *}$ & $-0.192^{* * *}$ \\
\hline & $(0.028)$ & $(0.027)$ & $(0.027)$ & $(0.028)$ & $(0.027)$ \\
\hline \multirow[t]{2}{*}{ HSD } & $-0.139^{* *}$ & $-0.128^{* *}$ & -0.096 & $-0.123^{* *}$ & -0.092 \\
\hline & $(0.064)$ & $(0.061)$ & $(0.061)$ & $(0.059)$ & $(0.059)$ \\
\hline \multirow[t]{2}{*}{$\mathrm{SMC}$} & $0.188^{* * *}$ & $0.163^{* * *}$ & $0.165^{* * *}$ & $0.164^{* * *}$ & $0.166^{* * *}$ \\
\hline & $(0.031)$ & $(0.031)$ & $(0.031)$ & $(0.031)$ & $(0.031)$ \\
\hline \multirow[t]{2}{*}{ CLC } & $0.367^{* * *}$ & $0.328^{* * *}$ & $0.313^{* * *}$ & $0.328^{* * *}$ & $0.311^{* * *}$ \\
\hline & $(0.032)$ & $(0.032)$ & $(0.032)$ & $(0.032)$ & $(0.032)$ \\
\hline \multirow[t]{2}{*}{ Labor market experience } & $0.024^{* * *}$ & $0.023^{* * *}$ & $0.022^{* * *}$ & $0.023^{* * *}$ & $0.022^{* * *}$ \\
\hline & $(0.003)$ & $(0.003)$ & $(0.003)$ & $(0.003)$ & $(0.003)$ \\
\hline \multirow[t]{2}{*}{ AGE } & $0.046^{* * *}$ & $0.047^{* * *}$ & $0.043^{* * *}$ & $0.050^{* * *}$ & $0.050^{* * *}$ \\
\hline & $(0.010)$ & $(0.010)$ & $(0.010)$ & $(0.017)$ & $(0.017)$ \\
\hline \multirow[t]{2}{*}{$\mathrm{AGE}^{\wedge} 2 / 100$} & $-0.062^{* * *}$ & $-0.062^{* * *}$ & $-0.057^{* * *}$ & $-0.068^{* * *}$ & $-0.068^{* * * *}$ \\
\hline & $(0.012)$ & $(0.012)$ & $(0.012)$ & $(0.021)$ & $(0.021)$ \\
\hline \multirow[t]{2}{*}{ 30-49 Age group } & & & & -0.033 & -0.045 \\
\hline & & & & $(0.062)$ & $(0.061)$ \\
\hline \multirow[t]{2}{*}{ 50-65 Age group } & & & & -0.012 & -0.019 \\
\hline & & & & $(0.100)$ & $(0.098)$ \\
\hline \multirow[t]{2}{*}{ ICT Skills } & $0.031^{*}$ & $0.030^{*}$ & $-0.052^{* *}$ & 0.043 & -0.036 \\
\hline & $(0.017)$ & $(0.017)$ & $(0.025)$ & $(0.029)$ & $(0.031)$ \\
\hline \multirow[t]{2}{*}{ ICT Skills x 30-49 Age group } & & & & -0.011 & -0.014 \\
\hline & & & & $(0.033)$ & $(0.032)$ \\
\hline \multirow[t]{2}{*}{ ICT Skills x 50-65 Age group } & & & & -0.032 & -0.036 \\
\hline & & & & $(0.049)$ & $(0.047)$ \\
\hline \multirow[t]{2}{*}{ Job Training } & & $0.155^{* * *}$ & $0.146^{* * *}$ & 0.053 & 0.046 \\
\hline & & $(0.025)$ & $(0.026)$ & $(0.043)$ & $(0.043)$ \\
\hline \multirow[t]{2}{*}{ Job Training x 30-49 Age group } & & & & $0.113^{* *}$ & $0.110^{* *}$ \\
\hline & & & & $(0.051)$ & $(0.051)$ \\
\hline \multirow[t]{2}{*}{ Job Training x 50-65 Age group } & & & & $0.190^{* *}$ & $0.189^{* *}$ \\
\hline & & & & $(0.083)$ & $(0.082)$ \\
\hline \multirow[t]{2}{*}{ LITERACY } & & & $0.120^{* * *}$ & & $0.120^{* * *}$ \\
\hline & & & $(0.026)$ & & $(0.026)$ \\
\hline \multirow[t]{2}{*}{ Constant } & $8.220^{* * *}$ & $8.121^{* * *}$ & $8.181^{* * *}$ & $8.132^{* * *}$ & $8.132^{* * *}$ \\
\hline & $(0.189)$ & $(0.189)$ & $(0.191)$ & $(0.290)$ & $(0.290)$ \\
\hline $\begin{array}{l}\text { Occupation and Industry Fixed } \\
\text { Effects }\end{array}$ & Yes & Yes & Yes & Yes & Yes \\
\hline \multicolumn{6}{|l|}{ Effects } \\
\hline R-Square & 0.433 & 0.446 & 0.453 & 0.449 & 0.456 \\
\hline Observations no. & 1993 & 1993 & 1993 & 1993 & 1993 \\
\hline
\end{tabular}

Notes: The dependent variable is the log of hourly earnings. The sample consists of full-time workers aged 16-65 who work at least 30 hours per week. Robust Standard errors are in parentheses. ${ }^{*} p<0.1,{ }^{* *} p$ $<0.05,{ }^{* * *} p<0.01$.

\section{Appendix Table 1 Wage Equation with Aging and ICT Skills, using IPW}




\begin{tabular}{|c|c|c|}
\hline & (1) & $(2)$ \\
\hline \multirow[t]{2}{*}{ Female } & $-0.192^{* * *}$ & $-0.204^{* * *}$ \\
\hline & $(0.027)$ & $(0.027)$ \\
\hline \multirow[t]{2}{*}{ HSD } & $-0.103^{*}$ & $-0.107^{*}$ \\
\hline & $(0.057)$ & $(0.058)$ \\
\hline \multirow[t]{2}{*}{ SMC } & $0.178^{* * *}$ & $0.164^{* * *}$ \\
\hline & $(0.031)$ & $(0.031)$ \\
\hline \multirow[t]{2}{*}{ CLC } & $0.311^{* * *}$ & $0.308^{* * *}$ \\
\hline & $(0.032)$ & $(0.032)$ \\
\hline \multirow[t]{2}{*}{ Labor market experience } & $0.023^{* * *}$ & $0.022^{* * *}$ \\
\hline & $(0.003)$ & $(0.003)$ \\
\hline \multirow[t]{2}{*}{ AGE } & $0.048^{* * *}$ & $0.048^{* * *}$ \\
\hline & $(0.017)$ & $(0.016)$ \\
\hline \multirow[t]{2}{*}{$\mathrm{AGE}^{\wedge} 2 / 100$} & $-0.065^{* * *}$ & $-0.065^{* * *}$ \\
\hline & $(0.021)$ & $(0.021)$ \\
\hline \multirow[t]{2}{*}{ 30-49 Age group } & -0.058 & -0.041 \\
\hline & $(0.061)$ & $(0.061)$ \\
\hline \multirow[t]{2}{*}{ 50-65 Age group } & -0.044 & -0.004 \\
\hline & $(0.099)$ & $(0.097)$ \\
\hline \multirow[t]{2}{*}{ ICT Skills } & -0.039 & -0.042 \\
\hline & $(0.031)$ & $(0.031)$ \\
\hline \multirow[t]{2}{*}{ ICT Skills x 30-49 Age group } & -0.041 & -0.006 \\
\hline & $(0.035)$ & $(0.034)$ \\
\hline \multirow[t]{2}{*}{ ICT Skills x 50-65 Age group } & -0.063 & $-0.091^{*}$ \\
\hline & $(0.051)$ & $(0.048)$ \\
\hline \multirow[t]{2}{*}{ ICT Skills x 30-49 Age group x High Educ } & $0.086^{* * *}$ & \\
\hline & $(0.033)$ & \\
\hline \multirow[t]{2}{*}{ ICT Skills x 50-65 Age group x High Educ } & 0.118 & \\
\hline & $(0.076)$ & \\
\hline \multirow[t]{2}{*}{ ICT Skills x 30-49 Age group x Skill Occ } & & -0.023 \\
\hline & & $(0.032)$ \\
\hline \multirow[t]{2}{*}{ ICT Skills x 50-65 Age group x Skill Occ } & & $0.202^{* *}$ \\
\hline & & $(0.082)$ \\
\hline \multirow[t]{2}{*}{ Job Training } & 0.045 & 0.047 \\
\hline & $(0.043)$ & $(0.043)$ \\
\hline \multirow[t]{2}{*}{ Job Training x 30-49 Age group } & $0.110^{* *}$ & $0.104^{* *}$ \\
\hline & $(0.051)$ & $(0.051)$ \\
\hline \multirow[t]{2}{*}{ Job Training x 50-65 Age group } & $0.201^{* *}$ & $0.189^{* *}$ \\
\hline & $(0.081)$ & $(0.080)$ \\
\hline \multirow[t]{2}{*}{ LITERACY } & $0.123^{* * *}$ & $0.127^{* * *}$ \\
\hline & $(0.026)$ & $(0.026)$ \\
\hline \multirow[t]{2}{*}{ Constant } & $8.158^{* * *}$ & $8.185^{* * *}$ \\
\hline & $(0.291)$ & $(0.277)$ \\
\hline Occupation and Industry Fixed Effects & Yes & Yes \\
\hline R-Square & 0.459 & 0.462 \\
\hline
\end{tabular}


Observations no.

1993

1993

Notes: The dependent variable is the log of hourly earnings. The sample consists of full-time workers aged 16-65 who work at least 30 hours per week. Robust Standard errors are in parentheses. ${ }^{*} p<0.1,{ }^{* *} p$ $<0.05,{ }^{* * *} p<0.01$.

Appendix Table 2 Wage Equation for Aging, Education, Occupation, and ICT Skills, using IPW 